\title{
English Language Teaching Strategies to Cope with the Barriers of ExtraLinguistic Factors for L2 Learners: A Qualitative Study in the Context of Public Sector Colleges Hyderabad, Sindh
}

\author{
Shumaila Bhatti* \\ MS English Linguistic Scholar \\ English Language Development Centre, Mehran University of Engineering and Technonology, \\ Jamshoro, Sindh, Pakistan \\ Shabana Sartaj \\ Department of English, Sindh Agriculture University, Tandojam, Pakistan \\ Waqar Ali Shah \\ English Language Development Centre, Mehran University of Engineering and Technology, \\ Jamshoro, Sindh, Pakistan
}

\begin{abstract}
The English teaching and learning is an increased demand of today's society. The English language students in public sector colleges faced difficulties to learn English whether as a foreign or second language. There are various extralinguistic factors that prevent students from reaching the goal of learning English. This research aims to probe those barriers connected with extralinguistic factors and find out some effective teaching strategies to cope with that issue at Government boys and girls'colleges of Heerabad, Hyderabad Sindh. The qualitative reseach method was used in the study. The research instrument was semi-structured interviews for data collection. The participants of the study were 14 male and female students $(m, n=7 \& f, n=7)$ and 6 male and female English teachers $(m, n=2$ $\& f, n=4)$ of the two public sector colleges of Hyderabad. The findings revealed that both male and female students used strategies in similarities and differences of results, where 'memory' and 'social' strategies that utilized by almost 'students' but more male students used social strategies than female students. The results also showed that teachers find out the implemented teaching strategies that were maximize learning opportunities, facilitate negotiated interaction were applicable and benficial and understand that social language learning strategies could be helpful for learning English. This study is significant as it could be helpful for several 'stakeholder' including instructors, policy makers, learners, teachers to comprehend the convolution involving L2 learning along with get aware to that strategies for coping the barriers.

Keywords:English language learning, Barriers in Extralinguistic factors, Postmethod teaching strategies, LLS, PMSFW, EFL, ESL.

DOI: $10.7176 /$ JLLL/74-05

Publication date: December $31^{\text {st }} 2020$

\section{INTRODUCTION}

In the global society English language plays an eminent role in speaking, it is a prestigious sign in order to achieve the economic profit, and its like a pass to enter in the market of global world, (Rehman, 2010; Shamim, 2010). To keep in view of such prestige, there is a serious necessity to achieve the English language proficiency for competing with the global world and get profits in several aspects of life which includes 'education' and 'employment'. In Pakistan, English is identified as L2 and in pedagogical point of view, it is used to teach as a 'compulsory subject' rather than as a 'language'. Therefore, students in public sector colleges are probably make mistakes in 'writing' and 'speaking' English language.
\end{abstract}

\section{Extralinguistic Factors}

Noor Aina Dani (2008) is an innovator of the extralinguistic factors, she refers these existed factors besides the second language. Those factors are relevant with the learning procedure, whether its 'English language learning', 'science' or 'mathematics'. The extralinguistic factors can be used in any field of the study. The classroom environment is the main factor of extralinguistic problem in ESL learning. While in an educational organization it depends on everything such as: curriculum design, teachers' behaviour with their student, methods of teaching, during teaching session the atmosphere, the academic and social environment and also the support system during stress.

\section{English Language Teaching and Learning}

The English language learning skills and its development have an impact on teaching and learning environment 
which manifested in the goal leading towards language teaching. The major issue for teaching practice is the production of a new language. In order to reach that teaching goal depended on various factors in outer and inner environmental conditions which evolved by the process of teaching. The general and major requirments for professional intellectuals making should be widely and deeply spread in all spheres of social life. In environmental conditions it should accompanied at both macro and micro level.

\section{Background of the Study}

Language learning Strategies Taxonomy: In 1960s, when the beginning of research into LLS, according to Williams \& Burden (1997), the development in 'cognitive psychology' influenced, alongside much research identified on LLS. Rubin and Wended (1987) recognizing what the report of the good learners of a language to do in order to learn EFL/ESL. While the strategies for learning, there is certain actions of learner to create learning 'easier', 'faster', 'more self-directed', 'more effective', 'more transferable' and more effective towards new circumstances.

PostMethod Condition: This method proposed by Kumaravadivelu (1994), this method can reshape the content and character of second language teaching, classroom research and teacher education. According to (Brown, 2000) in the beginning of 1970s, many researchers and teachers came to realize by the research findings that no method of teaching a second language would bring success completely, it was especially observed that regardless of methods and techniques of teaching certain learners were successful. Therefore, this newer understanding of teaching methodology in foreign language has been described as the "Postmethod condition" because of a set of newer assumption and beliefs surrounding foreign language teaching practices. In the general perception of this era, its' necessary for the language teacher to find the most effective techniques and strategies.

The present study is established on two models for the strategies of language learning and teaching English, 'language learning strategies' (LLS) taxonomy proposed by Oxford (1990) and PostMethod Strategic framework (PMSFW) by Kumaravadivelu (2001) that are helpful for L2 teachers' practice for coping with the extra-linguistic problems. This study not only focuses some peculiar problems relevant to language skill, but also found the difficulties to acquire and perceive to comprehend English language and the learning strategies through 'qualitative method'. Additionally, interviews were taken to discover L2 teaching along with learming difficulties, macro and micro strategies and some practical recommendations also given to solve these issues.

\section{Research Problem}

The English language teaching and learning depend upon the extralinguistic factors, such as; classroom environment, attitude, curriculum, behaviour, style and motivation, etc. In Sindh Pakistan English teachers and learners are facing difficulties and challenges towards English 'learning' and 'teaching' process. The English language is used as a lingua franca, official language, compulsory subject, communizing as an international language and also medium of instruction. Therefore, the importance of English language cannot be ignored. Abbas (1998), these researchers have agreed that after the hardwork and effort by English teachers, there is the failure rate in English learning is increasing day by day (Memon, Joubish \& Khurram, Mansoor, 2003).

The feeling of panic and barriers of extralinguistic factors in ESL learning that leads L2 learners towards 'distress of emotions' and it turns out in a negative result. These problems should be sort out completely for gaining desired outcomes. Consequently, the current research aims to identified the strategies English teachers practice to cope with the barriers of extra-linguistic factors L2 learners faced in English language learning in the context of Pakistan.

\section{Aim and Objectives}

The present research aims to draw attention on 'attitude' of Intermediate level students regarding the barriers of Extralinguistic factors in ESL learning and the effective teaching strategies to cope with the barriers of Extralinguistic factors in English language classrooms in the context of public sector colleges, Hyderabad Sindh. The purpose of the study is to get awareness about the barriers of L2 learners while learning English and observe the perceptions and attitudes of teachers towards PMSFW of teaching and LLS of 'English as a second language learning'. Specifically, the present study based on the following sub-objectives:

1. To address the barriers related to the Extralinguistic factors of 'Intermediate level' students towards 'English as a second language' learning at public sector colleges, Hyderabad Sindh.

2. To explore the attitude of students on helpful language learning strategies for enhancing L2 learning in public sector colleges.

3. To investigate the teaching strategies to cope with the barriers of Extralinguistic factors in

the implementation of postmethod framework strategies in public sector colleges,

Hyderabad, Sindh. 


\section{Research Questions}

The current study research questions are based on the above aims and objectives:

1. What are the barriers related to the Extralinguistic factors of 'Intermediate level'students towards 'English as a second language'learning at public sector colleges, Hyderabad Sindh?

2. What are the attitude of students on helpful language learning strategies for enhancing L2 learning in public sector colleges?

3. What are the English teaching strategies to cope with the barriers of Extralinguistic factors in the implementation of postmethod framework strategies in public sector colleges, Hyderabad Sindh?

\section{Significance of the study}

In the perception of the postmethod era, it is emphasized to the language teacher to find some effective teaching strategies, they need to view of their practitioners and their roles in preparing material for language teaching. The extralinguistic factors are the theoretical background of the current research. Noor Aina Dani (2008) the pioneer of the extra linguistic factors insisted on the awareness of L2 learners with the factors which are limited to the environment, behaviour, language exposure and motivation.

This current study is crucial because it can be profitable along with helpful for several stakeholders including; instructors, policy makers, learners, teachers for the sake of comprehending the complexity which involve in learning L2 and get aware with that coping strategies. This research can be profitable for the school administration which can bring some changes in their pedagogical approaches. Thus, this study can assist schools to improve the proficiency of learners in 'English learning'.

\section{LITERATURE REVIEW}

"Extralinguistic" is that word which means the collective knowledge. According to Schimdt (2010), the extralinguistic term refers with the language situations outside of the linguistic environment but the elements which considered as an extralinguitic elements in language learning is still taken into an account in order to give information about attitude, motivation, personality, emotion, behaviour and others, which has been proven to help a student to become master in a certain language.

\section{Attitude of Teachers towards teaching English as a second language:}

Nunan \& Nur (2003) conducted research on challenges in English teaching to young learners. There is one of the important challenge that faced by worldwide teachers and learners for English teaching as 'subject' rather than a 'language' in nonnative contexts. Moreover, (G. Hu, 2005\& Y. Hu, 2007) stated that there is deficiency of "English trained teachers" at schools to teach ESL. Hence, English teachers found themselves in an extremely challenging circumstances during English teaching to the 'young learners'. Likewise, there are many problems that students face while learning English language that results in an inability. "Classroom pedagogy" is another "potential challenge' that affected competence of L2 learning. In teaching ESL the recent advancement around universe have introduced some new pedagogical techniques and approaches.

\section{L1 Interference in L2 Acquisition}

Beardsmore (1982) learning a second or second L1 is interference, in attaining linguistic features such as vocabulary, phonology, and syntax, a learner faces many difficulties due to bad habits of transfer from L1 to L2. It is a common observation that L2 learners transmit their culture, learning habits and linguistic reservoir to L2, while trying to communicate in target language. Tariq et (2013) conducted study on problems faced ESL students that found environment factor is the main issue in learning L2.

\section{Challenges of Pedagogy}

In L2 teaching there are several challenges for 'English teachers' among them one of such challenge is a 'large class' size. In large classes speaking activities create noise that many times disturb the neighbouring classes even all around the environment are affected with that noise (Carless, 2004). Butler (2005) observed another in crowded class that 'English teachers' challenge face is that of 'observing' and 'discipline' as noted.

\section{English Curriculum\& Language Teaching in L2 Setting}

The textbooks taught in L2 setting is more content based which aims to propagate ideologies and shape stereotypes about ethnicity, race, gender and religion. There is a lack of activities which foster language learning in L2 classes. Richards et al (1992) states that the textbooks need to be compatible with modern approaches which teach language more than the content. And for that "Needs Assessment" (NA) is an integral part of designing a course. 


\section{Research Gap}

In the area of problems in teaching and learning English language, the researcher studied different studies that have been investigated on the issues, such as; barriers and problems, conditions about English taught in Pakistan (Warsi, 2004), problems and difficulties faced by students in ESL (Tariq, 2013), problems of learners in writing skills (Haider, 2012), elite and non-elite schools (Khattak, 2014). The Problems and barriers relevant to teaching English in Pakistan (Shamim, 2017). But as per record available, there is dearth of research on the barriers of extralinguitic factors of public sector students in English as L2 learning and the teaching strategies to cope with the barriers on speaking and writing skills, which have room for the present study.

\section{Theoretical Framework}

The present study used two models' framework: Language learning strategy framework by Oxford (1990) and PostMethod Strategic framework by Kumaravadivelu (2001).

\section{Language learning strategy framework}

The term language learning strategy is used to the awareness of learners' specific actions for the purpose of English language learning, its motive of LLS as being aligned to develop the competence of communication. Rebecca Oxford (1990) divided the two main types of language learning strategies 'direct' and 'indirect' strategies further produced the six categories in learning strategies, direct strategies are used to attract the learners' attention in the form of direct communication and vocabulary meanings, these strategies are independent learning that learners pursue on their own, (direct strategies) included; 'memory', 'cognitive', 'compensation', on the other side indirect strategies help in language learning which indirectly involved in a target language, (indirect strategies) included; 'social', 'affective' and 'metacognitive' strategies which are helpful in the present study for teachers as key features to know about the suitable and workable learning startegies for students. The direct and indirect strategies are:

- "Cognitive Strategies": Summarizing, outlining, note-taking, practicing in naturalistic settings, receiving and sending messages strategies, practicing sounds and structures.

- "Memory Strategies": Memory-related strategies can enable learners to learn and reacquire information in learning and reacquire via sounds, pictures, e.g; (the meaning of the word or a mental picture of the word, body movement), e.g; total physical response.

- "Compensation Strategies": Help in missing knowledge, using gestures or pause words, guessing from the context to talk about any missing word around it in order to helpout speaking, writing and also using synonyms.

- "Metacognitive Strategies": Arranging and planning students' learning and also evaluating students' learning.

- "Affective Strategies": These strategies are helpful for learners to control their feelings and to regulate their attitudes, emotions and motivation.

- "Social Strategies": These type of strategies support 'learners' to do work in collaboration with people and to comprehend others language and also their 'targeted culture'.

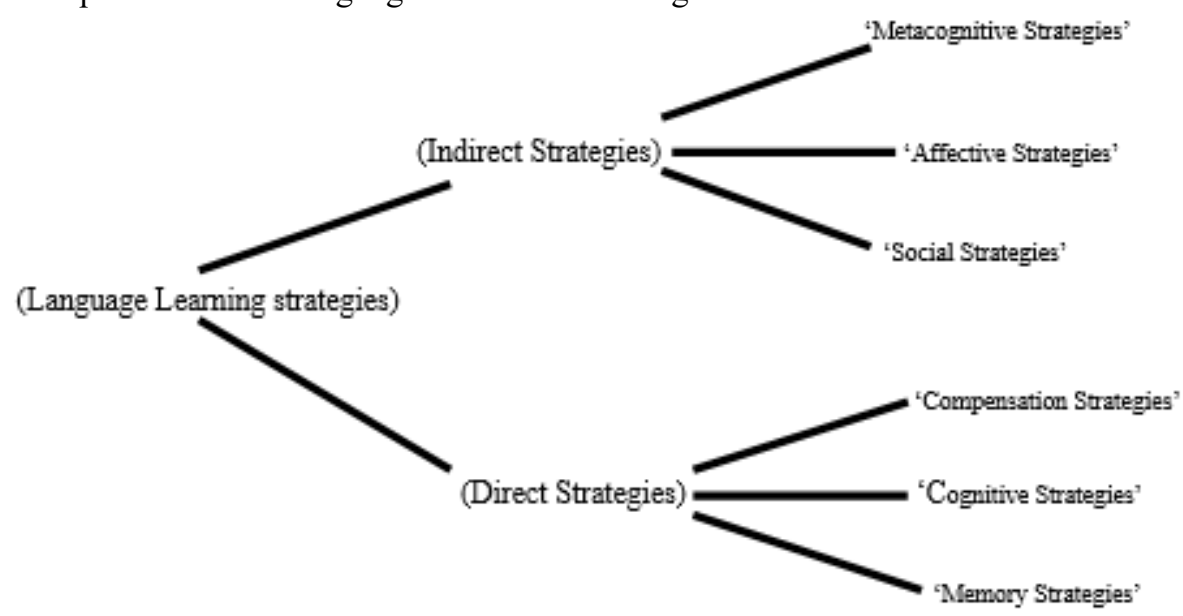

(Language Learning Strategy Framework) by Oxford (1990)

\section{Postmethod strategic framework for $\mathrm{L} 2$ teaching}

In the present study this framework used as a theory and strategies, it offers not only the teaching and learning strategies for teaching practices but also supplies strategies and techniques to analyze the process of 'English as a 
ESL/EFL learning' to cope with EL problems. It provides the guideline for 'teachers' on that their teaching based in order to get awareness of teaching procedure and become able to defend it. According to Kumaravadivelu (1994) the 'postmethod pedagogy' is pivotal for teachers 'professional development' as it connects to build teachers 'orientation in classroom' theories of practice. Kumaravadivelu's framework (2001), proposed for teaching strategies are divided into two types: Macrostrategies and Microstrategies.

Macro Strategies:The ordinary plans derived through the empirical, pedagogical and theoretical knowledge relevant along with L2 'teaching and learning' are macrostrategies. Thus, these strategies have guidelines that depend on teachers, through macrostrategies they produce some own 'need-based', 'situation-specific' classroom techniques/ microstrategies.

Micro Strategies:In order to acknowledge the objectives of a particular strategies, the microstrategies can be designed which are included in the classroom procedures. Each macrostrategies can have any type of, and any number of microstrategies which depends on the local teaching and learning situation. This study used five macrostrategies for that one or two microstrategies are designed as following:

- Minimize perceptual mismatches: Teachers should minimize the gap that present between 'learner and teacher' comprehending and encouraging inside the 'classroom activities and objectives', (Think aloud).

- Activate Intuitive Heuristics: This type of macrostrategy refers to the self-discovery process of the learner part, (seeing is learning. surf the net).

- Facilitate negotiated interaction: This type of macro-strategy depends upon 'teacher-learner' and 'learner-learner' meaningful fundamental-interaction inside the context of classroom, there learner should be given freedom to initiate talk, (Hard talk, striking a bargaining).

- Maximize learning opportunities: The teaching process to utilize and create opportunities of learning, here 'teachers' are creators for opportunities of learning for their learners/students and also teachers being as users for opportunities of learning which are created by learners, (Cyberspace, competition game).

- Foster Language Awareness:The main focus of language awareness about language involves on the 'language properties' usage along with 'language structure' besides peculiar reference for 'writing and reading' as literary skills, (spell it out, speech act practices).

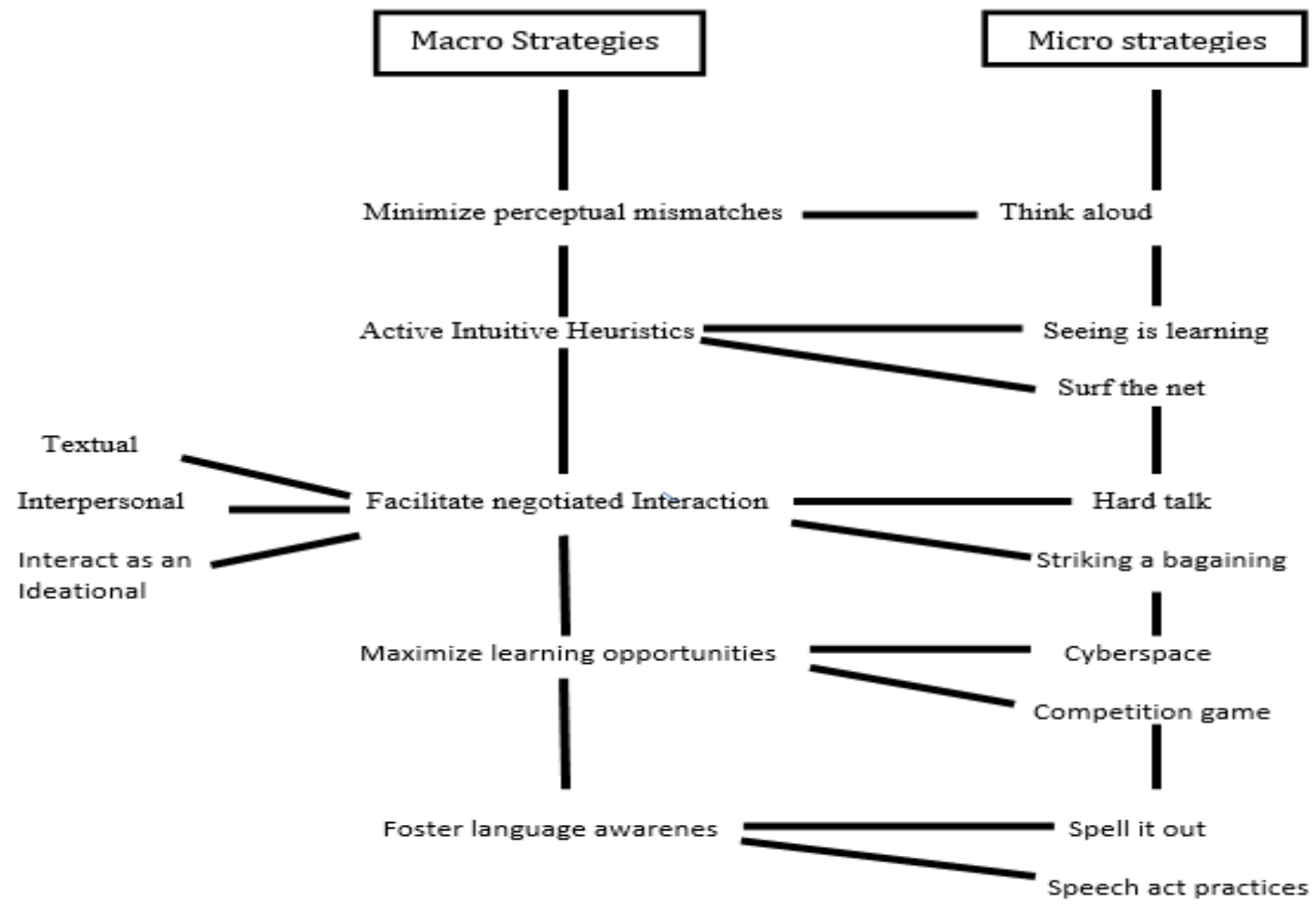

(Postmethod Strategic framework for L2 teaching) by Kumaravadivelu (2001)

\section{RESEARCH METHODOLOGY}

The qualitative research is used in the present study, it involves with relevant events, or any quality or kind. This research methodology discovers the motives along with underlying desires utilizing in-depth interviews for this aim different researches designed on opinion and attitude in order to find out 'how people feel' and what they think about a peculiar 'institution' or 'subject' is qualitative research. 
A crucial role plays in the research of qualitative method in behavioural science, there is objective towards 'human behaviour' reveal the motives. Kumar (2008) states this type of study help the researcher to get the answers in detail from the participants that analysis the different elements which can encourage people to act in a peculiar manner, or which includes dislike or like among people choices in a peculiar thing.

\section{Participants of the research}

The prime focus of this paper is to investigate the teaching strategies that cope with the barriers of Extralinguistic factors in the implementation of 'language learning and teaching' frameworks. This study selected 14 participants (male and female) students among them $(n=7$ male and $n=7$ female) and 6 male and female English teachers among them (4 female and 2 male) from two different colleges of Heerabad district Hyderabad, Sindh. The semistructured interviews used as a research tool.

\section{Procedure of interview data collection}

The researcher managed to select participants using purposive sampling from two public sector colleges which are easy to reach for collecting the data. The researcher gets the pre and post interviews from teachers. Hence, for the post interview teachers were requested to read the given frameworks of LLS and PMSFW in order to teach their students and implented those strategies in their classroom context. The researcher started pre-interview with very simple questions investigating their teaching experience, then post-interview was collected from teachers, after two weeks of taken the pre-interview. The interview conducted from student participants about the barriers of Extralinguitic factors. The researcher informed to the participants that their interview is being recorded and the transcriptions given to the teacher participants for the member checking test.

\section{Data Analysis and findings}

This study used thematic analysis by Braun and Clarke (2006) for analyzing the interview data. The researcher familiarized with the data through listening interviews several times for the transcription of the data, therefore the transcription helped the researcher to identify codes to analyze the data. The researcher needs to understand the answers of the interviewquestions in more depth, so that the researcher was made themes in order to codify the data. The participants responses were randomly selected to labeled the categories and the interview was assembled in the form of following themes:

Codes, Themes and the sample responses among Students (ST)

\begin{tabular}{|c|c|}
\hline Theme & ubthemes response of sample \\
\hline Theme 1: & Extralinguistic barriers in English language learning \\
\hline Overcrowded & The student interviewees (F) ST1, ST2, ST5, ST6, ST7 \& (M) ST1, ST2, ST3, ST7 \\
\hline Classrooms & and they respond as: When I learn English overcrowded classroom is the mian obstacle. \\
\hline Environment effects & $\begin{array}{l}\text { The student interviewees (F) ST1, ST3, ST4\& (M) ST2, ST4 and they respond as: The } \\
\text { environment effects on L2 learning such as seating arrangement, electricity and other } \\
\text { physical condition of the classes. }\end{array}$ \\
\hline Old Syllabus & $\begin{array}{l}\text { The student interviewees (F) ST5, ST6 \& (M) ST5, ST6,ST7 and they respond } \\
\text { as: Intermediate syllabus is not sufficient for learning opportunities. }\end{array}$ \\
\hline Code-switching & $\begin{array}{l}\text { The student interviewees (F) ST1, ST2, ST3 \& (M) ST2, ST4, ST6, ST7 and they respond } \\
\text { as: I try to speak in English but sindhi/urdu sentences mixed up, L1 interference in L2 } \\
\text { (code-switching). }\end{array}$ \\
\hline
\end{tabular}

\section{Theme 2: $\quad$ Helpful language learning strategies}

Group discussion \& Group work

Self-encouragement \& learner autonomy

Store-information \& Remember Information
The student interviewees (F) ST2, ST4, ST5 they respond that: when teacher give task, I sit with my classmates for group discussion and (M) ST1, ST2, ST3, ST4 they respond as: I increase my knowledge through group work including charts making and assignment.

The student interviewees (F) ST1, ST3, ST6, ST7, they respond that: I learn English from mistakes, getting hint from teacher and also by encouraging my self to do the best and (M) ST2, ST4, ST6 I learn English by myself, I try to show expressions or emotions while miss the accurate word's meaning.

The student interviewees (F) ST5, ST6, ST7. They respond that: I store the information when teacher shown the flashcards or images that information helpful for me many times and (M) ST3, ST5, ST6, ST7, they respond as: I store previous information that help me to learn a language by remembering information. 


\section{Extralinguistic barriers in English language learning}

The Extralinguistic barriers in learning English language addressed by male and female student participants in majority $(M \& F, n=9)$ said that overcowded classrooms create problem for them in learning English language. In the other statement, participants $(\mathrm{M} \& \mathrm{~F}, \mathrm{n}=5)$ viewed that Environment effect on their English as a second language learning including seating arrangement, electricity and the other phyiscal condition of classroom. Moreover, some interviewees shared that the Intermediate syllabus is not sufficient for their enhancing English language learning opportunities. However, some participants viewed that they have problems regarding L1 interference in L2 that is code-switching.

\section{Helpful language learning strategies}

The student interviewees shared their views regarding the helpful English language learning strategies in L2 classes. The female participants $(n=3)$ said that they sit with their classmates for group discussion whenever teacher give them task, while male interviewees $(n=4)$ viewed they make charts and assignment through group work, both male and female participants showed their interest in Social stratgies. Furthermore, some female participants $(n=4)$ shared that they learn from their mistakes that is metacognitive strategies in which students monitoring their mistakes, through getting hints from teacher and also they encourage themselves to do their best, whereas male participants $(n=3)$ learn by self-autonomy, they show expressions or emotions while they miss the accurate meaning of the vocabulary word as it shows that male students use compensation strategies. However, female and male participants $(n=7)$ said that they store their previous information that help them many times to make them able to learn English language by remembering the information, this statement shows both male and female participants learn thorugh memory-related startegies as to reacquire information.

Codes, Themes and the sample responses among English Teachers (ET)

\begin{tabular}{ll}
\hline Theme & Subthemes response of sample \\
\hline Theme 3: & English general teaching strategies \\
\hline Teaching Grammar & The English Teacher interviewees (F) ET1\& (M) ET6 and they respond as: I use \\
\& vocabulary learning & $\begin{array}{l}\text { different teaching strategies to enable students learn English, i.e; grammar, vocabulary } \\
\text { learning. } \\
\text { The English Teacher interviewees (F) ET4\& (M) ET5 and they respond as: I teach } \\
\text { With the help of 'Grammar Translation Method' because students feel hesitation in large } \\
\text { classes, they do not understand lectures in English language in public sector colleges. }\end{array}$ \\
\hline
\end{tabular}

Theme 4: Enhancing L2 learning with Postmethod framework teaching strategies

Student-centred Environment

Interactive teaching Strategies

Writing task

Freedom to talk
The English Teacher interviewees (F) ET2 \& she responds as: I focus on student-centred learning environment, so I give task i.e; writing the summary of poem, memorize words.

The English Teacher interviewees (F) ET3 \& she responds as: I make practices for students become more active in the classroom context, so I use the interactive teaching strategies.

The English Teacher interviewees (M) ET5 \& he responds as: I prefer essay and Letter writing task to enhance their L2 learning and reduce their fear of writing in the exams. The English Teacher interviewees (M) ET6 \& he responds as: I teach my students in the enviornment of freedom, where they can ask any question when they need and free talk and give presentation task, I use maximize learning opportunities.

\section{English general teaching strategies}

In the pre-interview English teachers interviewed about the general teaching strategies. The male and female teacher participants $(\mathrm{F}, \mathrm{n}=\mathrm{ET} 1)$ and $(\mathrm{M}, \mathrm{n}=\mathrm{ET} 6)$ said that they use different strategies to enable students learn English such as teaching grammar and vocabulary learning. Moreover, other participants (F, n=ET2) and (M, $\mathrm{n}=\mathrm{ET} 5$ ) viewed that they teach with the help of grammar translation method because in public sector colleges students feel hesitation in large classes, therefore they do not understand lectures in English language.

\section{Enhancing L2 learning with Postmethod framework teaching strategies}

In the post-interview English Teachers shared their experiences in the implemented postmethod strategic framework, where macro and micro teaching strategies are applicable in their L2 teaching and also shared their understanding about the LLS through learners'specific actions while learning English. One of the female teacher interviewee said that her focus is on creating student-centred learning classroom environment with the use of active intuitive heuristics strategies, where instruction shifted from teacher to the student. However, another female 
participant ( $n=$ ET3) viewed that she makes practice for students become more active in the classroom with the use of interactive teaching strategies of facilitate negotiated interaction, where social strategies can be more helpful for students. Moreover, the male teacher interviewee $(n=E T 5)$ said that he prefers essay and letter writing task to enhance their L2 learning and reduce students fear of writing in the examination. The other male participant $(\mathrm{n}=$ ET6) viewed that he teaches in the environment of freedom by implementing the maximize learning opportunities he gives priority to free talk and ask questions whenever students need to ask and presentation task for competition game. Therefore, almost English teachers found that the both strategic frameworks are applicable and beneficial to implement in public sector colleges but when the students present as 25 to 30 in classroom.

\section{DISCUSSION}

The current research investigated the English language teaching strategies to cope with those barriers that are relevant to the extralinguistc factors for L2 learners in public sector colleges Heerabad, Hyderabad Sindh. The students were interviewed in order to investigate the barriers of extralinguistic factors that make them unsuccessful in speaking and writing skills during English learning as a 'foreign or second language' that are overcowded classroom, environment effect, old syllabus and code-switching. As according to Tariq et al (2013) highilghted Pakistan ESL students faced problems, where the main issue in learning English is environment factors. The helpful language learning strategies also investigated from their responses that are memory and social strategies used by almost students, whereas metacognitive and compensation strategies are also helpful for few students, while the result came in the 'differences and similarities' in between 'female and male' students choices of utilizing "language learning strategies", it came to know that male students are more extrovert or social than female students. According to Oxford (1990) said that 'strategies of learning' which taken the learners peculiar actions to intensify learning 'faster', 'more transferable', more effective and easier to new circumstances.

In the present study the researcher conducted pre and post interview from English teachers, in pre-interview teachers were investigated about the general teaching startegies that they used in their English classes, although the researcher found that teachers were using old methods of grammar tanslation, vocabulary learning and teaching grammar in public sectors, there is lack of effective teaching and learning strategies in public sector colleges, therefore the PMSFW and LLS were suggested to the teachers to read and implement in their classroom for the sake of intensifying learning L2 and to cope along with those barriers relevant to extralinguistic factors. In postinterview English teachers were appreciated both the models as almost teachers interested in developing their teaching strategies with the help of macro strategies are maximize learning opportunities, intuitive heuristics strategies, facilitate negotiated interaction and maximize learning opportunities and micro strategies free talk in role play, interaction with teachers or students, searching words then guess the meaning through memorizing new words, presentations for competition game, and teachers suggested the social strategies for L2 learners. Only two female teachers ( $\mathrm{n}=$ ET1 \& ET4) were not much interested to apply new strategies in their classes as they said they do not have much time to apply the different strategies, it's a fact that no research get the complete solution of the investigated problems. As Block (1996) said the differences and similarities between the learners and teachers'perception is the purpose of learning for L2 learners.

\section{Conclusion}

The teaching and learning English language is the demand of today's world. In Sindh, Pakistan students of public sector instititutions are from different backgrounds, they need different language learning and teaching strategies to practice 'EFL' or 'ESL' classes. This study revealed that there are various barriers of extralinguistic factors such as; overcrowded classroom, environment effect on L2 learning, old syllabus, lack of motivation that increase chances of hesitation in students behaviour and code-switching, all these factors created problems regarding 'EFL or ESL' for 'pubic sector students'. The current research focused on the need of effective teaching strategies in order to cope with the barriers of extralinguitic factors that pevent students to learn English language, therefore teachers have dire need to develop their teaching strategies in the implementation of PMSFW and to understand the LLS to become aware with the learners specific actions and needs.

\section{References}

Abbasi,A.M, (2011). A Survey of Teaching Strategies in ESL Classroom. Language in India, volume 11: 11, ISSN1930-2940.

Akram, M. \& Qureshi, H. A. (2012). Problems in Learning and Teaching English Pronunciation in Pakistan. Int'l Journal of Research in linguistics \& Lexicography. 4(1), 43-48

Ansari,A (2008). Teaching of English, Aligarh, India.

Bilal, H. A. Rehman, A. Rashi, C. H. A. Adnan, R. Abbas, M. (2013). Problems in Speaking English with L2 Learners of Rural Area School of Pakistan. European Journal of Humanities and Social Sciences, 24(1), $1222-122$

Braun, V., and Clarke, V., "Using thematic analysis in psychology", Qualitative research in Psychology, vol. 3, 
no.2, p.77-101 (2006).

Creswell, J.W. (2003). Research Design: Qualitative, Quantitative \& Mixed methods. Thousand Oaks: CA: Sage. Dugan, R. R.,"Personality and the effective teacher," Journal of Teacher Education, vol.12, no.3 (1961).

Gabriel, B (2018). Students' perceptions of using a second language in a mother tongue dominated environment: contrastive analysis. International Journal for Innovation Education and Research.

Huang, C. (2007). Why Do University Students want to learn English? Master Thesis, Providence University.

Huda, M. E. (2013). Post-Method Pedagogy and ELT in Bangladesh. Global Journal of Human Social Science, XIII(VII).

Khan, T.J \& Khan, N (2016). Obstacles in learning English as a second language among intermediate students of Districts Mianwali and Bhakkar, Pakistan. Open Journal of Social sciences, 4, 154-162.

Nunan D (1991). Language Teaching Methodology: A Textbook for Teachers.

Nunan, D. (2003). The impact of English as a global language on educational policies and practices in the AsiaPacific region. TESOL Quarterly, 37, 589-613.doi :10.2307/3588214

Nur, C. (2003). English language teaching in Indonesia: Changing policies and practical constraints. In W. K. Ho \& R. Y. L. Wong (Eds.), English language teaching in East Asia today: Changing policies and practices (pp. 163-172). Singapore.

Shamim, F. (2012). Teaching large classes. In A. Burns \& J. C. Richards (Eds.), The Cambridge guide to pedagogy and practice in second language teaching (pp. 95102). New York, NY: Cambridge University Press.

Soomro \& S. Almalki (2017). Language practitioners' reflections on method-based and post-method pedagogies, canadian center of science and education. English language teaching: Vol. 10, no.5. 